\title{
Modulation of Striatal Dopamine Release by Glycine Transport Inhibitors
}

\author{
Daniel C Javitt*, ${ }^{*, 2}$, Audrey Hashim ${ }^{1,2}$ and Henry Sershen ${ }^{1,2}$ \\ 'Department of Neurochemistry, Nathan S Kline Institute for Psychiatric Research/NYU School of Medicine, Orangeburg, NY, USA; ${ }^{2}$ Program in \\ Cognitive Neuroscience and Schizophrenia, Nathan S Kline Institute for Psychiatric Research/NYU School of Medicine, Orangeburg, NY, USA
}

\begin{abstract}
Traditional models of schizophrenia have focused primarily upon dopaminergic (DA) dysregulation. In contrast, more recent models focus on dysfunction of glutamatergic systems, acting particularly through N-methyl-D-aspartate (NMDA) receptors. NMDA receptors in brain are regulated by glycine, acting via a strychnine-insensitive regulatory site, and by glycine (Gly TI) transporters that maintain low glycine levels in the immediate vicinity of the NMDA receptor complex. The present study investigates the role of NMDA receptors in the modulation of striatal dopamine release in vitro, and of glycine transport inhibitors (GTIs) as potential psychotherapeutic agents in schizophrenia. In striatum, NMDA receptors exert dual excitatory/inhibitory effects, with inhibition reflecting activity of local GABAergic feedback regulation. We have previously demonstrated effectiveness of glycine in regulating $\left[{ }^{3} \mathrm{H}\right] \mathrm{DA}$ release both in vivo and in vitro, consistent with its beneficial clinical effects. In the present study, similar effects were observed for the high-affinity GTI ( + )N[3-(4'fluorophenyl)-3-(4'-phenylphenoxy-)propyl]sarcosine (NFPS), and for a range of high-affinity GTIs with appropriate rank order of potency. In addition, (+)NFPS significantly stimulated NMDA-induced $\left[{ }^{3} \mathrm{H}\right] \mathrm{GABA}$ release. Effects, of GTls, were blocked by the glycinesite antagonists $\mathrm{L689,560}$ and $\mathrm{HA}-966$, and the GABA $\mathrm{B}_{\mathrm{B}}$ antagonists phaclofen and CGP 52432, confirming the roles of both the NMDAassociated glycine-site and presynaptic $G_{A B A}$ receptors in NMDA receptor-mediated regulation of striatal DA release in vitro. Endogenous DA hyperactivity is associated with prominent positive symptoms in schizophrenia. The present results are consistent with recent clinical studies showing significant effectiveness of glycine-site agonists and GTIs in reduction of persistent positive, as well as negative, symptoms in schizophrenia.

Neuropsychopharmacology (2005) 30, 649-656, advance online publication, 26 January 2005; doi: I 0. I 038/sj.npp. I 300589
\end{abstract}

Keywords: glutamate; NMDA receptor; amphetamine; phencyclidine; schizophrenia

\section{INTRODUCTION}

Schizophrenia is a severe brain disease that affects up to $1 \%$ of the world's population. Traditional models of schizophrenia emphasize the importance of dopaminergic (DA) dysregulation (eg, Davis et al, 1991; Moore et al, 1999), particularly in the etiology of positive symptoms. More recent models, in contrast, emphasize the potential role of $\mathrm{N}$-methyl-D-aspartate (NMDA) receptor dysfunction as a basis for both persistent negative and cognitive symptoms, and DA dysregulation in schizophrenia (Javitt, 1987, 2004; Carlsson and Carlsson, 1990; Javitt and Zukin, 1991; Coyle, 1996; Hirsch et al, 1997; Abi-Saab et al, 1998; Olney et al,

\footnotetext{
*Correspondence: Dr DC Javitt, Program in Cognitive Neuroscience and Schizophrenia, Nathan S Kline Institute for Psychiatric Research, I 40 Old Orangeburg Road, Room S235, Orangeburg, NY 10962, USA, Tel: + I 845398 6534, Fax: + I 845398 6545,

E-mail: javitt@nki.rfmh.org

Received 22 March 2004; revised II August 2004; accepted 9 September 2004

Online publication: I 3 September 2004 at http://www.acnp.org/citations/ Npp09|30404/34/default.pdf
}

1999; Moghaddam and Jackson, 2003). This reconceptualization of schizophrenia has led to efforts both to develop more effective NMDA-stimulating agents, and to define critical sites of interaction between dopamine and NMDA systems.

In schizophrenia, DA dysregulation, particularly in striatum, has been confirmed through in vivo neuroimaging (Abi-Dargham et al, 1998; Breier et al, 1997; Laruelle, 1998; Laruelle et al, 1996). NMDA receptors are present in high density in striatum, and are localized on both presynaptic DA terminals and on GABA interneurons where they serve to inhibit presynaptic DA release through local feedback regulation (Wu et al, 2000). NMDA receptor antagonists, such as phencyclidine (PCP) or ketamine, induce schizophrenia-like DA dysregulation in both animals (Balla et al, 2001, 2003; Miller and Abercrombie, 1996) and normal human volunteers (Kegeles et al, 2000). Further, mice with mutations of the NMDA $\varepsilon 1$ subunit show both biochemical and behavioral evidence of DA dysregulation (Ballard et al, 2002; Miyamoto et al, 2001). Dysfunction or blockade of NMDA receptors particularly on GABA interneurons may, therefore, produce DA hyperactivity similar to that observed in schizophrenia. 
NMDA receptors in brain are regulated both by glutamate, which serves as the primary agonist, and glycine, which binds to an allosteric modulatory site (Dingledine et al, 1990; Reynolds and Miller, 1990). Glycine levels in brain, in turn, are regulated by glycine transporters including the glycine type I (GlyT1) transporter. GLYT1 transporters are colocalized with NMDA receptors and serve to 'protect' the NMDA site from high circulating levels of glycine (Lopez-Corcuera et al, 2001; Smith et al, 1992). One recent approach to NMDA potentiation, therefore, has been the development of glycine transport inhibitors (GTIs), which prevent glycine removal from the synaptic cleft thereby increasing occupancy of the NMDA/glycinebinding site (Javitt and Frusciante, 1997; Javitt et al, 1997; Supplisson and Bergman, 1997).

In initial studies, the prototypic glycine transport inhibitor glycyldodecylamide (GDA) significantly inhibited PCP-induced hyperactivity in rodents (Javitt et al, 1999; Toth et al, 1986) and reversed NMDA-induced DA release from rat striatal slices (Javitt et al, 2000). More recently, high-affinity glycine transporter inhibitors such as $N\left[3-\left(4^{\prime}-\right.\right.$ fluorophenyl)-3-(4'-phenylphenoxy)propyl] sarcosine (NFPS, ALX5407) (Atkinson et al, 2001; Herdon et al, 2001) have been shown to potentiate NMDA receptor-mediated neurotransmission both in vitro (Bergeron et al, 1998) and in vivo (Chen $e$ al, 2003); to normalize prepulse inhibition (Kinney et al, 2003; Le Pen et al, 2003); and to reverse PCP-induced DA dysregulation in vivo (Javitt et al, 2003). However, mechanisms underlying DA reregulation produced by NMDA agonists, including both glycine and newly developed glycine transport inhibitors, remain to be determined. In the present study, an in vitro striatal release assay, shown previously to be sensitive to effects of glycine and the prototype glycine transport inhibitor GDA (Javitt et al, 2000), was used to evaluate effects of newly developed glycine transport inhibitors on striatal DA and GABA release, and to investigate mechanisms underlying NMDA/ DA/GABA interactions.

\section{METHODS}

Mice were decapitated and the striatal tissue (approximately $8-10 \mathrm{mg}$ ) was dissected out and incubated for $60 \mathrm{~min}$ in $\mathrm{Mg}^{2+}$-containing $0.5 \mathrm{ml}$ of Krebs bicarbonate buffer containing 1.25-3.0 $\mu \mathrm{Ci}\left[{ }^{3} \mathrm{H}\right]$ dopamine (New England Nuclear, Boston, MA) and, where applicable, $1.2 \mu \mathrm{Ci}\left[{ }^{14} \mathrm{C}\right] \mathrm{GABA}$. For striatal dissections, the mouse brain was partially dissected in half and the cortex carefully folded outwards with a small spatula to expose the striatum from each hemisphere. The area of the striatum was visible from the surrounding region by their striated texture. The spatula was used to undercut the region slightly below the surface and to remove the striatal tissue; approximately $15 \mathrm{mg}$ for both left and right striatum. For experiments involving GABA, amino-oxyacetic acid $(0.1 \mathrm{mM})$ was added to the incubation buffer. The reaction mixture was continuously gassed with an $\mathrm{O}_{2} / \mathrm{CO}_{2}$ mixture $(95 \% / 5 \%)$. After prelabeling, tissue was transferred to superfusion chambers $(12 \times 0.3 \mathrm{ml}$ chambers, Brandel Superfusion 1200, MD) and preperfused at a rate of $0.8 \mathrm{ml} /$ min for $60 \mathrm{~min}$ in the above buffer minus $\mathrm{Mg}^{2+}$. Effluent was discarded during this period and thereafter 3 or $4 \mathrm{~min}$ fractions were collected for an additional 45-60 min, depending on the experiment. Blocking drugs were added before indicated fractions and maintained until the end of the experiment.

Enhanced release was induced by addition of NMDA, at indicated doses, during fraction 5 (2 min exposure). Fractional release was defined as radioactivity content of each fraction divided by the amount of radioactivity remaining in the tissue at the time the fraction was collected. For studies using $25 \mu \mathrm{M}$ NMDA, NMDA-induced release was defined as the area under the fractional release curve for 24 min following NMDA exposure (fractions 611 ), relative to surrounding fractions. For studies using $300 \mu \mathrm{M}$ NMDA, NMDA-induced release was defined as the summed release during the post-NMDA exposure period (fractions 6-15), relative to baseline.

Following the perfusion period (fraction 15), the tissue was removed from the perfusion chamber along with the remaining perfusion buffer, sonicated, and assayed for tissue radioactivity. To determine radioactivity released from the tissue, the perfusate $(2.4 \mathrm{ml})$ was mixed with $3 \mathrm{ml}$ Liquiscint scintillation fluid (National Diagnostics, Atlanta, Georgia) and counted in a Packard Scintillation Counter (Model 1500).

Effects of GTIs on synaptosomal glycine transport were determined as previously described (Javitt and Frusciante, 1997). Assays were performed using a concentration of $1 \mu \mathrm{M}$ of prospective GTIs.

Data in text represent mean $\pm S D$. Two-tailed statistics with preset alpha level for significance of $p<0.05$ are used throughout.

\section{RESULTS}

The goal of this study was to investigate effects of newly developed GTIs on NMDA-stimulated DA release in rodent striatum. Initial studies were performed with enantiomers of ALX5311, a high-potency GTI structurally related to NFPS. Subsequent studies were performed with the resolved enantiomers $(+)$ and (-)NFPS. L689,560, a high-affinity NMDA/glycine-site antagonist (Stauch Slusher et al, 1994) and HA-966 (Javitt et al, 2000), a partial agonist, were used to evaluate involvement of NMDA receptors in GTI-induced effects. The $\mathrm{GABA}_{\mathrm{B}}$ agonist baclofen, and antagonists phaclofen (Kerr et al, 1987) and CGP52432 (Teoh et al, 1996) were used to evaluate potential $G_{A B A}$ receptor involvement.

\section{Effect of Glycine Transport Inhibitors on NMDA-Induced Dopamine Release}

An initial set of studies was performed in Balb/c mice. In the absence of added ligands, brief exposure of $25 \mu \mathrm{M}$ NMDA induced a robust increase in dopamine efflux that peaked immediately following NMDA exposure and decayed over the ensuing $28 \mathrm{~min}$ (seven fractions). Initial studies were performed using $1 \mu \mathrm{M}$ ALX5311, a potent, selective GTI (Figure 1). ALX5311 inhibited NMDA-induced dopamine release in a dose-dependent fashion $(\mathrm{F}=4.82, \mathrm{df}=3 / 126$, $p=0.003$ ) with highly significant inhibition being observed at a dose of $1 \mu \mathrm{M}(t=3.75, \mathrm{df}=116, p<0.0001)$ (Figure 2a). 
Further, the $(+)$ enantiomer exerted significantly greater inhibition of release than the $(-)$ enantiomer $(t=3.03$, $\mathrm{df}=19, p=0.014$ ).

In order to determine role of the NMDA-associated glycine site in this effect, studies were repeated in the presence of the selective glycine-site antagonist L689,560 and the partial antagonist HA-966 (Figure 2b). NMDAinduced DA release was significantly inhibited by L689,560 itself in a dose-dependent fashion, with significant inhibition being observed at a dose of $100 \mathrm{nM}(t=3.94, \mathrm{df}=103$, $p<0.0001)$. In the presence of L689,560, no significant effects of ALX5311 were observed $(t=1.14, \mathrm{df}=36, p=0.3)$.

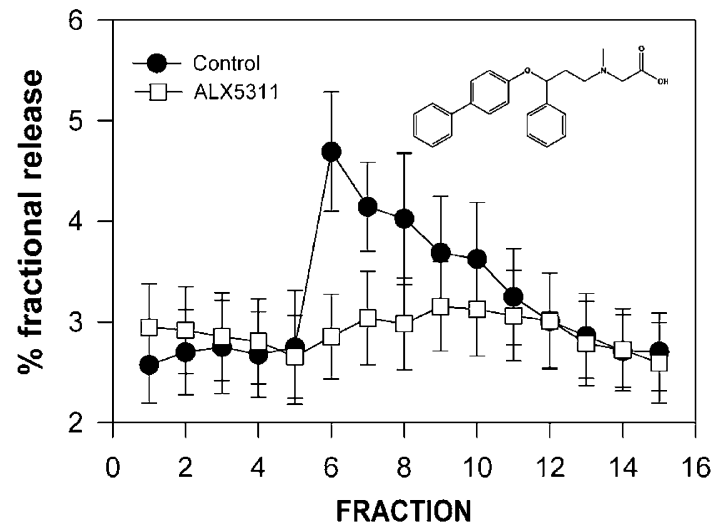

Figure I Fractional NMDA-stimulated $\left[{ }^{3} \mathrm{H}\right] \mathrm{DA}$ release in the absence and presence of the high-affinity glycine transport inhibitor $A L X 531$ I $(I \mu M)$. Structure of $A L X 53||$ is shown in inset. Fractions were collected every 4 min. Data are mean \pm SEM. $* p<0.05$ vs control; $* * * 0.01$ vs control.

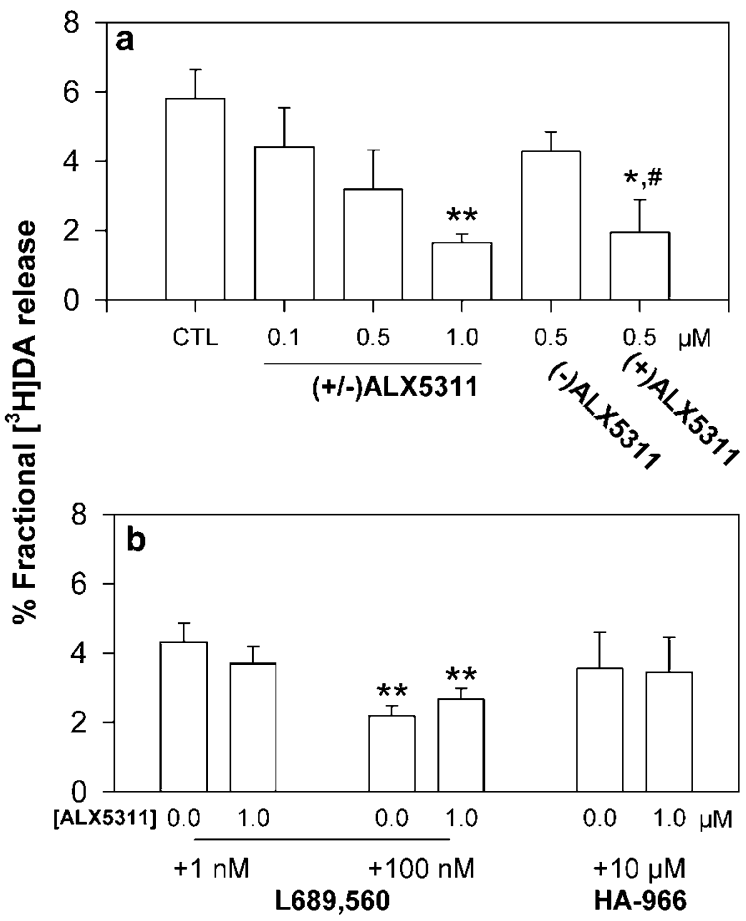

Figure 2 Summed NMDA-stimulated $\left.{ }^{3} \mathrm{H}\right] \mathrm{DA}$ release in the absence and presence of $(+)$ and $(-) A L X 53 \mid I$ (a) and in the additional presence of the NMDA/glycine-site antagonists L689,560 and HA-966 (b). ${ }^{*} p<0.0$ I vs control, *** $<0.00$ I vs control; $\# p<0.05$ vs $(-)$ ALX53II.
When data were entered into a $2 \times 2$ ANOVA, a significant L689,560 $\times$ ALX5311 interaction emerged $(\mathrm{F}=7.68, \mathrm{df}=$ $1 / 152, p=0.006)$, reflecting the significant effects of ALX5311 in the absence but not the presence of L689,560. HA-966 alone did not significantly inhibit NMDA-induced DA release at a concentration of $10 \mu \mathrm{M}$. Nevertheless, in the presence of HA-966, no significant further effect of ALX5311 was observed.

In order to verify the effects of ALX5311, experiments were repeated with the subsequently developed, selective GLYT1 inhibitor (+) NFPS. As with ALX5311, the $(+)$ isomer shows greater affinity for the GLYT1 transporter than the (-) isomer (Kinney et al, 2003; Mallorga et al, 2003), permitting differential effectiveness studies to be performed. $(+)$ NFPS was significantly more effective than $(-)$ NFPS $(t=2.32, \mathrm{df}=37, p=0.05)$, which was without significant effect (Figure 3). Across this series of NFPS-type drugs, the degree of inhibition of $\left[{ }^{3} \mathrm{H}\right] \mathrm{DA}$ release correlated significantly with the degree of inhibition of synaptosomal glycine transport $(p=0.01)$.

Owing to the change in institutional breeding policies, a second set of studies with $(+)$ NFPS was performed in C57BL/6 mice to verify stability of effect across strains (Figure 4). In order to optimize conditions, studies were performed in both the absence and presence of added glycine $(100 \mu \mathrm{M})$. In tissue from these mice, $(+)$ NFPS also induced significant, dose-dependent inhibition of NMDAstimulated $\left[{ }^{3} \mathrm{H}\right] \mathrm{DA}$ release $(\mathrm{F}=5.0, \mathrm{df}=2 / 334, p=0.007)$. The effect of glycine was significant only at trend level $(\mathrm{F}=3.3, \mathrm{df}=2 / 334, p=0.07)$. No significant glycine $\times$ $(+)$ NFPS interaction was observed $(\mathrm{F}=1.5, \mathrm{df}=2 / 334$, $p=0.2$ ).

\section{Effect of GTIs on $\left[{ }^{3} \mathrm{H}\right] \mathrm{GABA}$ Release}

One hypothetical mechanism by which GTIs might induce their effects is by modulation of GABAergic feedback regulation. In order to investigate effects of GTIs on striatal GABAergic function, striata were dually preincubated with $\left[{ }^{14} \mathrm{C}\right] \mathrm{GABA}$ and $\left[{ }^{3} \mathrm{H}\right] \mathrm{DA}$. For these experiments, a higher

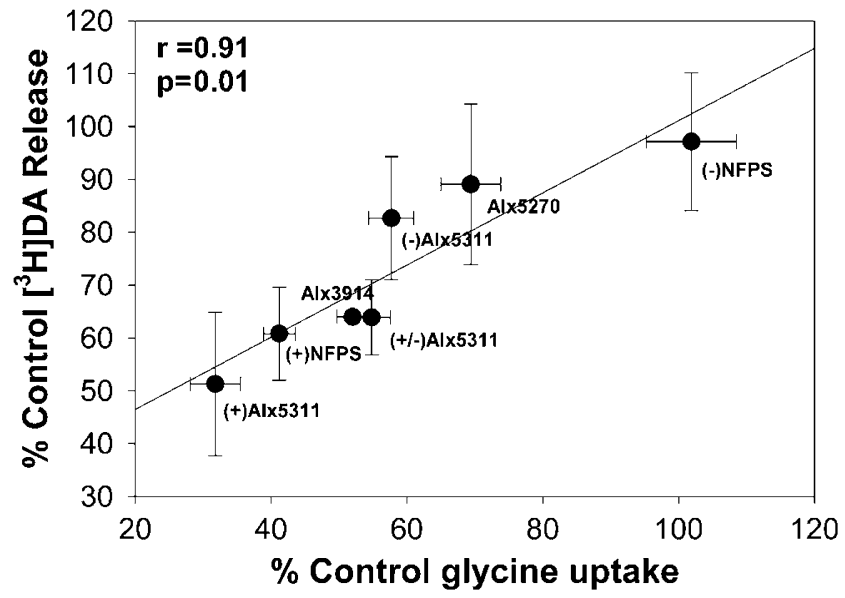

Figure 3 Correlation between degree of inhibition of NMDA-stimulated $D A$ release in mouse striatal release assay at concentrations of I $\mu \mathrm{M}$ and degree of inhibition of $\left.{ }^{3} \mathrm{H}\right]$ glycine uptake in a rat synaptosomal $\left[{ }^{3} \mathrm{H}\right]$ glycine uptake assay. 


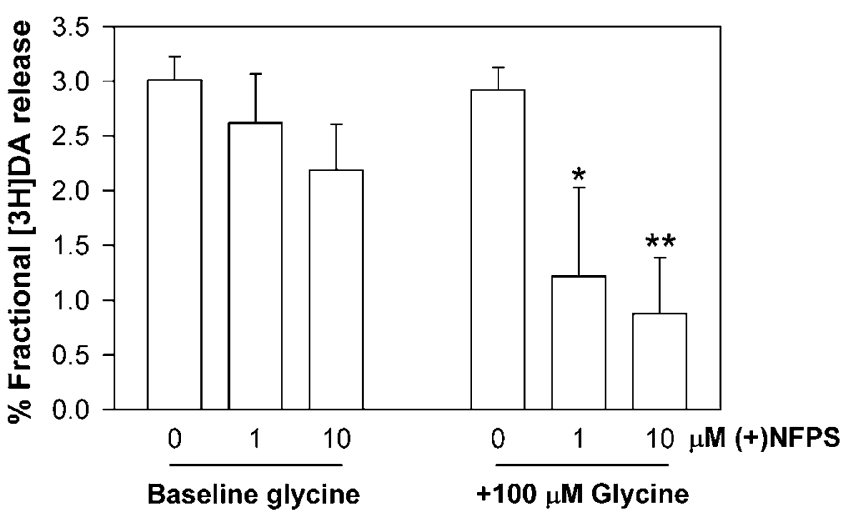

Figure 4 Effect of the high-affinity GTI (+)NFPS on (a) basal, and (b) NMDA-stimulated $\left.{ }^{3} \mathrm{H}\right]$ release in the absence and presence of added glycine $(100 \mu \mathrm{M})$. Fractions were collected every $3 \mathrm{~min}$. $* 0<0.01$; *** $p<0.00$ I vs control.

dose $(300 \mu \mathrm{M})$ of NMDA was used to increase release levels. $(+)$ NFPS was employed at a dose of $10 \mu \mathrm{M}$. In this experiment, compounds were added at fraction 1 to permit greater evaluation of effects on basal release, as well as on NMDA-stimulated DA release. L689,560 (100 nM) was used to evaluate NMDA/glycine-site dependence of $(+)$ NFPS effects.

As in prior studies, $(+)$ NFPS had no effect on basal $\left[{ }^{3} \mathrm{H}\right] \mathrm{DA}$ release in either the absence $(t=.1, \mathrm{df}=100$, $p=0.9)$ or presence $(t=1.35, \mathrm{df}=52, p=0.2)$ of added L689,560 (Figure 5a). In contrast, L689,560 (100 nM) significantly enhanced basal release of $\left[{ }^{3} \mathrm{H}\right] \mathrm{DA}(t=3.07$, $\mathrm{df}=94, p=0.003)$. An ANOVA revealed a significant main effect of L689,560 $(\mathrm{F}=9.4, \mathrm{df}=1 / 152, p=0.003)$, on basal DA release, but no significant main effect of $(+)$ NFPS $(\mathrm{F}=2.1, \mathrm{df}=1 / 152, p=0.1)$ or $(+) \mathrm{NFPS} \times \mathrm{L} 689,560$ interaction $(\mathrm{F}=1.9, \mathrm{df}=1 / 152, p=0.2)$.

As in prior experiments, $(+)$ NFPS significantly inhibited NMDA-induced release $\left[{ }^{3} \mathrm{H}\right] \mathrm{DA}$ in an L689,560-dependent fashion (Figure 5b). In the absence of added L689,560, significant inhibition by $(+)$ NFPS was observed $(t=3.61$, $\mathrm{df}=100, p<0.001)$. L689,560 by itself also inhibited NMDAinduced release $(t=4.68, \mathrm{df}=94, p<0.001)$. However, in the presence of L689,560, (+)NFPS had no significant further inhibitory effect $(t=0.4, \mathrm{df}=52, p=0.7)$. ANOVA, therefore, revealed a significant main inhibitory effect of $\mathrm{L} 689,560 \quad(\mathrm{~F}=14.6, \mathrm{df}=1 / 152, p<0.001)$. Although $(+)$ NFPS had no significant effect on its own $(F=3.1$, $\mathrm{df}=1 / 152, p=0.08)$, the $(+)$ NFPS $\times$ L689,560 interaction effect was significant $(\mathrm{F}=5.71, \mathrm{df}=1 / 152, p=0.02)$, reflecting the differential effect in the presence $v s$ absence of added glycine-site antagonist and confirming prior observations.

Predicted effects of $(+)$ NFPS were also observed on GABA release. Thus, both basal $(\mathrm{F}=14.8, \mathrm{df}=1 / 224$, $p<0.001$ ) (Figure 5c) and NMDA-stimulated $(\mathrm{F}=9.97$, $\mathrm{df}=1 / 224, p=0.002)$ (Figure $5 \mathrm{~d}$ ) release of $\left[{ }^{14} \mathrm{C}\right] \mathrm{GABA}$ was significantly higher in the presence of $(+)$ NFPS than in its absence. However, L689,560 had a more complex effect, in that it significantly increased basal release $(\mathrm{F}=11.1$, $\mathrm{df}=1 / 224, p=0.001)$, but significantly inhibited NMDAinduced release $(\mathrm{F}=4.74, \mathrm{df}=1 / 224, p=0.03)$. No significant $(+)$ NFPS X L689,560 interaction were observed for a Basal Release
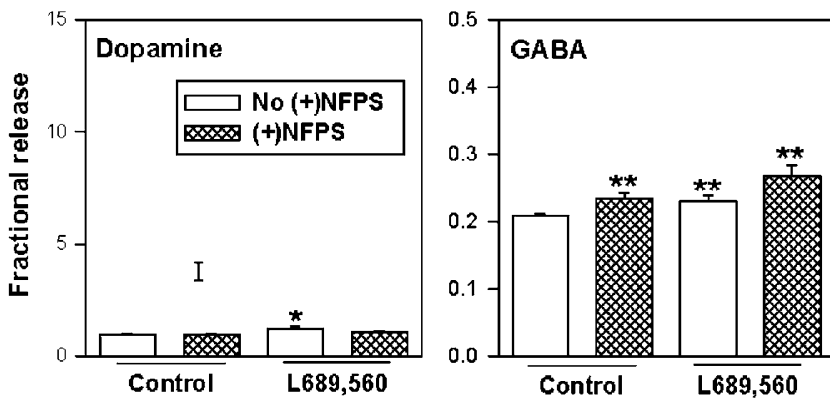

b NMDA-stimulated release
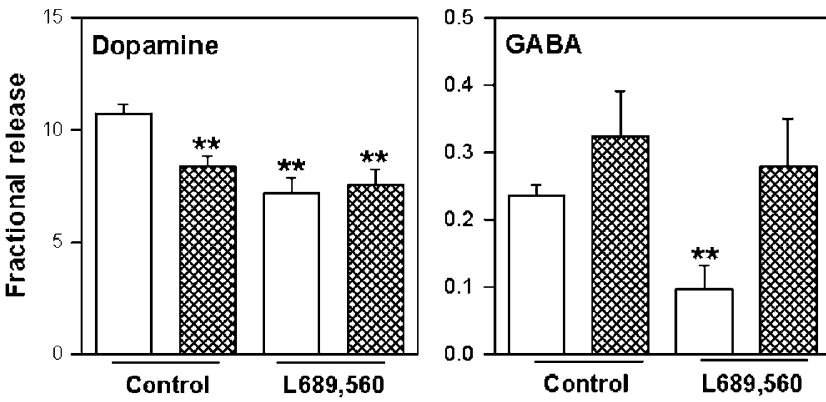

Figure 5 Effect of $(+)$ NFPS $(10 \mu M)$ on basal (a) and NMDAstimulated (b) DA and GABA release in the absence and presence of L689,560 (I $00 \mathrm{nM}$ ). ${ }^{*} p<0.05$ vs ctl; ${ }^{*} * 0<0.0$ I vs control.

either basal $(\mathrm{F}=.5, \mathrm{df}=1 / 224, p=0.5)$ or NMDA-stimulated $(\mathrm{F}=1.26, \mathrm{df}=1 / 224, p=0.3)$ release. These findings demonstrate the predicted ability of GTIs to enhance NMDA-regulated GABA release in striatum, although it suggest the presence of multiple sites of action for L689,560.

\section{Effect of $\mathrm{GABA}_{B}$ Ligands}

A final series of experiments evaluated potential mechanisms by which GTIs mediate their effects. The most likely basis for the inhibitory effects is a modulation of GABAergic neurotransmission. GABA mediates its effects at $\mathrm{GABA}_{a}$ receptors, which are sensitive to the selective $G_{A B A}$ antagonist bicuculline, and $\mathrm{GABA}_{\mathrm{b}}$ receptors, which are sensitive to the selective agonist baclofen and the selective antagonists phaclofen and CGP52432. Bicuculline had no significant effect on $\left[{ }^{3} \mathrm{H}\right] \mathrm{DA}$ release either on its own or in combination with $(+)$ NFPS (data not shown). Subsequent studies, therefore, examined effects of $\mathrm{GABA}_{\mathrm{b}}$ ligands.

In this experiment, a dose of $(+)$ NFPS of $25 \mu \mathrm{M}$ was used (Figure 6). As in previous experiments, (+)NFPS produced a highly significant reduction in fractional $\left[{ }^{3} \mathrm{H}\right] \mathrm{DA}$ release $(t=4.54, \mathrm{df}=262, p<0.001)$. Experiments were repeated in the presence of the $\mathrm{GABA}_{\mathrm{b}}$ receptor agonist baclofen $(100 \mu \mathrm{M})$, and the antagonists phaclofen $(50 \mu \mathrm{M})$ and CGP52432 $(1 \mu \mathrm{M})$. Baclofen on its own significantly inhibited DA release $(t=4.91, \mathrm{df}=166, p<0.001)$. Moreover, in the presence of baclofen, $(+)$ NFPS produced no further significant inhibition, and even a tendency toward significant increase $(t=1.81, \mathrm{df}=35, p=0.08)$, leading to a significant NFPS $\times$ baclofen interaction $(\mathrm{F}=8.7, \mathrm{df}=1 / 164$, $p=0.004)$ (Figure 7). 


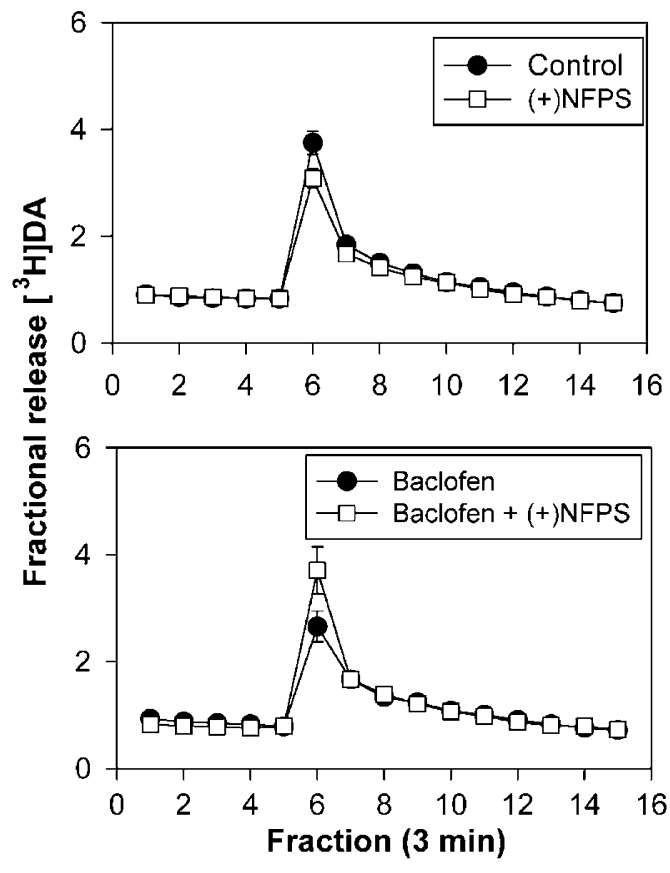

Figure 6 Effect of $(+)$ NFPS $(25 \mu \mathrm{M})$ on NMDA (300 $\mu \mathrm{M})$-stimulated $\left[{ }^{3} \mathrm{H}\right] \mathrm{DA}$ release in the absence and presence of the $\mathrm{GABA}_{B}$ agonist baclofen $(100 \mu \mathrm{M})$.

No significant reduction in $\left[{ }^{3} \mathrm{H}\right] \mathrm{DA}$ release was observed following treatment with the $\mathrm{GABA}_{\mathrm{b}}$ antagonists phaclofen $(t=1.07, \mathrm{df}=76, p=0.3)$ or CGP52432 $(t=1.41, \mathrm{df}=76$, $p=0.6$ ) (Figure 7). Nevertheless, in the presence of GABA antagonists, $(+)$ NFPS was without effect. In the CGP52432 experiments, there was no significant effect of either CGP52432 $(\mathrm{F}=0.9, \quad \mathrm{df}=1 / 211, \quad p=0.3) \quad$ or $(+)$ NFPS $(\mathrm{F}=0.8, \mathrm{df}=1 / 211, p=0.4)$, but the CGP52432 $\times(+)$ NFPS interaction was significant $(\mathrm{F}=6.1 \mathrm{df}=1 / 211, p=0.015)$, reflecting the differential $(+)$ NFPS effect in the absence $v s$ presence of $\mathrm{GABA}_{\mathrm{b}}$ antagonists. Similarly, in the phaclofen experiments, an ANOVA revealed no significant effect of either phaclofen $(\mathrm{F}=1.7, \mathrm{df}=1 / 211, p=0.2)$ or $(+)$ NFPS $(\mathrm{F}=1.8, \mathrm{df}=1 / 211, p=0.2)$. However, the phaclofen $-\times$ $(+)$ NFPS interaction was significant $(\mathrm{F}=4.0, \mathrm{df}=1 / 211$, $p=0.045)$, replicating the CGP52432 results.

\section{DISCUSSION}

Current treatments for schizophrenia target the dopamine system primarily by blockade of dopamine $\mathrm{D}_{2}$ receptors. More recent theories have suggested alternative use of drugs targeted at the NMDA receptor (Javitt, 2001; Javitt and Zukin, 1991). 'First-generation' agents that have been used in clinical studies include both glycine (Heresco-Levy et al, 2004; Heresco-Levy et al, 1999; Javitt et al, 2001; Javitt et al, 1994) and D-serine (Tsai et al, 1998), which are endogenous agonists, as well as the synthetic glycine/D-serine derivative D-cycloserine, which is a partial agonist (Goff et al, 1999; Heresco-Levy et al, 1998). Development of high-affinity glycine-site agonists, however, is limited by the small molecular size of the target (McBain et al, 1989). A more recent approach has been the development of GTIs (Atkinson et al, 2000; Bergeron et al, 1998; Javitt, 2002;

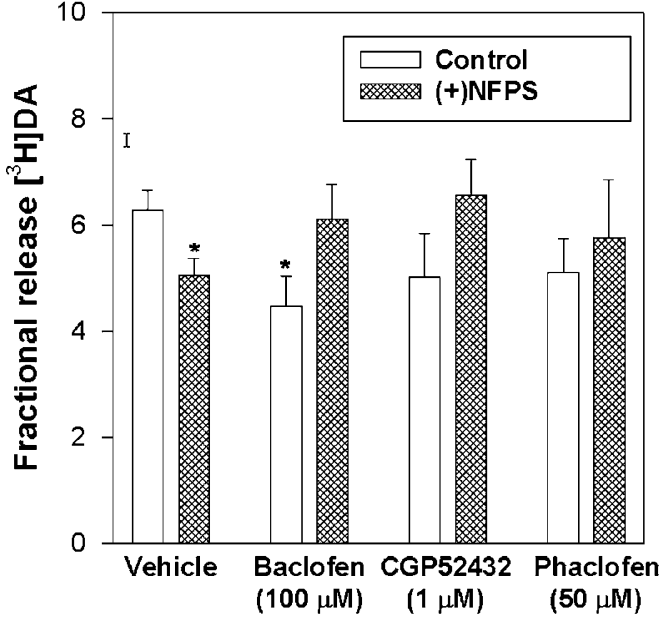

Figure 7 Effects of $(+)$ NFPS $(25 \mu \mathrm{M})$ on NMDA $(300 \mu \mathrm{M})$-stimulated $\left[{ }^{3} \mathrm{H}\right]$ release in the absence and presence of the $\mathrm{GABA}_{B}$ agonist bacofen $(100 \mu \mathrm{M})$ and the GABA $\mathrm{B}_{\mathrm{B}}$ antagonists CGP52432 (I $\left.\mu \mathrm{M}\right)$ and phaclofen $(50 \mu \mathrm{M}) . *{ }^{*} p<0.05$ vs control.

Javitt and Frusciante, 1997). This approach is analogous to use of selective noradrenaline or serotonin reuptake inhibitors, rather than noradrenaline or serotonin precursors, to influence brain monoamine levels in depression, or use of GABA transport inhibitors to elevate brain GABA levels in epilepsy or other brain hyperexcitability states (Dalby, 2003). The primary finding of the present study is that high-affinity GTIs show significant in vitro efficacy in potentiating NMDA-stimulated GABA release in striatum, and that this effect leads to significant inhibition of striatal DA release, an effect that would be expected to be therapeutically beneficial in schizophrenia.

The present results support a model in which NMDA receptors have dual excitatory-inhibitory function within striatum (Leviel et al, 1989; Taber et al, 1996). The excitatory effects of glutamate are most likely mediated at NMDA receptors located on presynaptic dopamine terminals. The existence of such receptors is well documented (Gracy and Pickel, 1996; Krebs et al, 1991; Wang, 1991). However, ultrastructual evidence of functional axoaxonal glutamatergic synapses on DA terminals is lacking, suggesting that the receptors may have limited physiological relevance. In the present study, NMDA stimulation of DA release via these receptors serves to mimic the impulsedependent DA release that would normally be elicted by corticonigral activation in response to psychostimulant agents such as amphetamine, permitting analysis of feedback mechanisms within the system. Inhibitory effects of NMDA are mediated through NMDA receptors located on intrinsic GABAergic interneurons. Infusion of NMDA into striatum in intact animals increases both DA and GABA release (Hernandez et al, 2003), consistent with this model. Further, GABAergic inhibitory mechanisms in striatum have been demonstrated in both rodent (Hanania and Johnson, 1999; Hernandez et al, 2003) and primate (Schiffer et al, 2003) striatum, demonstrating in vivo relevance of this pathway to intrinsic DA regulation.

In brain, extracellular glycine levels are sufficient to fully saturate the NMDA/glycine-binding site. GTIs are 
postulated to function by regulating synaptic, relative to extracellular, levels, leading to local protection of the NMDA/glycine-binding sites (Supplisson and Bergman, 1997). In the present study, GTIs did not affect presynaptic DA release, presumably due to the absence of functional synapses and of a protected intrasynaptic space, but did increase NMDA-stimulated GABA release consistent with the existence of ultrastructurally demonstrated glutamatergic synapses on GABAergic interneurons. In contrast, L689,560, which inhibits glycine binding at both presynaptic and postsynaptic receptors, inhibited both DA and GABA release. GTIs were without significant effect on DA release in the presence of L689,560, confirming the role of increased glycinergic stimulation at the NMDA/glycine site in mediating their effects. Interestingly, while GTIs stimulated striatal GABA release and L689,560 inhibited release, there was no significant interaction between the two treatments. This may indicate hetereogeneity either of GABA/NMDA interactions or NMDA subtypes in striatum (Nankai et al, 1995). Nevertheless, both effects were in the predicted direction, with presumed NMDA stimulators increasing striatal GABA release and the NMDA antagonist decreasing GABA release.

The role of dopamine in the pathophysiology of schizophrenia has been appreciated for at least the past 40 years. Recent in vivo imaging studies have confirmed the relation between striatal dopamine release and have suggested that increased striatal dopamine levels may serve as a final common mechanisms for generation of positive psychotic symptoms. Thus, striatal dopamine levels are increased not only by DA agents such as amphetamine (Laruelle et al, 1999) but also by NMDA antagonists such as PCP and ketamine (Breier et al, 1998), with the degree of increase correlating with the level of psychotic symptoms. Further, normalization of striatal dopamine release accompanies clinical remission of positive symptoms in schizophrenia despite persistence of negative symptoms (Laruelle et al, 1999). The ability of glycine (Javitt et al, 2000) and GTIs (this study) to reduced striatal dopamine release is consistent with recent observations that NMDA agonists such as glycine (Heresco-Levy et al, 2004), D-serine (HerescoLevy et al, submitted; Tsai et al, 1998), and the naturally occurring GTI sarcosine (Tsai et al, 2004) significantly ameliorate persistent positive, as well as negative, psychotic symptoms in schizophrenia, with positive symptom effects most likely reflecting effects on striatal NMDA/DA interactions.

Finally, the present study demonstrates a significant involvement of $\mathrm{GABA}_{\mathrm{B}}$ receptors in mediating the effects of NMDA-stimulated GABA release on DA inhibition. This effect is consistent with known localization of $G_{A B A}$ receptors to presynaptic DA terminals (Smolders et al, 1995), and the ability of $\mathrm{GABA}_{\mathrm{B}}$ agonists to partially inhibit NMDA-induced striatal tyrosine hydroxylase stimulation in NMDA (Arias Montano et al, 1992; Arias-Montano et al, 1991).

Although the present study focuses on GTI potentiation of NMDA receptor-mediated neurotransmission within striatum, this is unlikely to be the sole site of psychotherapeutic action of these agents. GTIs, for example, have been shown to stimulate NMDA receptor-mediated neurotransmission in both hippocampus (Bergeron et al, 1998) and prefrontal cortex (Chen et al, 2003), areas of the brain associated with prominent disability and negative symptom generation in schizophrenia. The present results, however, suggest that even DA dysregulation in schizophrenia may be attributable to NMDA dysfunction, and that NMDA stimulatory agents may exert significant psychotherapeutic effects even for positive symptoms. A limitation of the study is that an in vitro model system was used. Replication of these results in vivo with more recently developed, systematically active GTIs, therefore, will be critical.

In summary, this is the first study to demonstrate significant modulation of striatal dopamine release by high-affinity GTIs, and one of small number of studies to date validating the GTI concept as a method for stimulating systems-level NMDA receptor-mediated neurotransmission. These studies are encouraging of continued development of GTIs as novel psychotherapeutic agents in schizophrenia and related neuropsychiatric disorders.

\section{ACKNOWLEDGEMENTS}

This study was supported by USPHS grants DA03383 and MH01439 and by a Burroughs-Wellcome Translational Scientist Award to DCJ. (+)NFPS and related compounds were provided for research use by Trophix Pharmaceuticals (S Plainfield, NJ), now NPS Pharmaceuticals, Inc. (Salt Lake City, UT). The study had no commercial sponsorship.

\section{REFERENCES}

Abi-Dargham A, Gil R, Krystal J, Baldwin RM, Seibyl JP, Bowers M et al (1998). Increased striatal dopamine transmission in schizophrenia: confirmation in a second cohort. Am J Psychiatry 155: 761-767.

Abi-Saab WM, D'Souza DC, Moghaddam B, Krystal JH (1998). The NMDA antagonist model for schizophrenia: promise and pitfalls. Pharmacopsychiatry 31(Suppl 2): 104-109.

Arias-Montano JA, Martinez-Fong D, Aceves J (1991). Gammaaminobutyric acid (GABAB) receptor-mediated inhibition of tyrosine hydroxylase activity in the striatum of rat. Neuropharmacology 30: 1047-1051.

Arias Montano JA, Martinez-Fong D, Aceves J (1992). GABAB receptor activation partially inhibits $N$-methyl-D-aspartatemediated tyrosine hydroxylase stimulation in rat striatal slices. Eur J Pharmacol 218: 335-338.

Atkinson BN, Bell SC, De Vivo M, Kowalski LR, Lechner SM, Ognyanov VI et al (2001). ALX 5407: a potent, selective inhibitor of the hGlyT1 glycine transporter. Mol Pharmacol 60: 1414-1420.

Atkinson BN, DeVivo M, Lechner SM, Kowalski L, Zheng Y, Klitenick MA (2000). Characterization of ALX-5407, a GLYT1selective reuptake inhibitor. Soc Neurosci Abs 26: 1653.

Balla A, Koneru R, Smiley J, Sershen H, Javitt DC (2001). Continuous phencyclidine treatment induces schizophrenia-like hyperreactivity of striatal dopamine release. Neuropsychopharmacology 25: 157-164.

Balla A, Sershen H, Serra M, Koneru R, Javitt DC (2003). Subchronic continuous phencyclidine administration potentiates amphetamine-induced frontal cortex dopamine release. Neuropsychopharmacology 28: 34-44.

Ballard TM, Pauly-Evers M, Higgins GA, Ouagazzal AM, Mutel V, Borroni E et al (2002). Severe impairment of NMDA receptor function in mice carrying targeted point mutations in the glycine binding site results in drug-resistant nonhabituating hyperactivity. J Neurosci 22: 6713-6723. 
Bergeron R, Meyer TM, Coyle JT, Greene RW (1998). Modulation of $\mathrm{N}$-methyl-D-aspartate receptor function by glycine transport. Proc Natl Acad Sci USA 95: 15730-15734.

Breier A, Adler CM, Weisenfeld N, Su TP, Elman I, Picken L et al (1998). Effects of NMDA antagonism on striatal dopamine release in healthy subjects: application of a novel PET approach. Synapse 29: 142-147.

Breier A, Su TP, Saunders R, Carson RE, Kolachana BS, de Bartolomeis A et al (1997). Schizophrenia is associated with elevated amphetamine-induced synaptic dopamine concentrations: evidence from a novel positron emission tomography method. Proc Natl Acad Sci USA 94: 2569-2574.

Carlsson M, Carlsson A (1990). Interactions between glutamatergic and monoaminergic systems within the basal ganglia-implications for schizophrenia and Parkinson's disease. Trends Neurosci 13: 272-276.

Chen L, Muhlhauser M, Yang CR (2003). Glycine tranporter-1 blockade potentiates NMDA-mediated responses in rat prefrontal cortical neurons in vitro and in vivo. J Neurophysiol 89: 691-703.

Coyle JT (1996). The glutamatergic dysfunction hypothesis for schizophrenia. Harv Rev Psychiatry 3: 241-253.

Dalby NO (2003). Inhibition of gamma-aminobutyric acid uptake: anatomy, physiology and effects against epileptic seizures. Eur J Pharmacol 479: 127-137.

Davis KL, Kahn RS, Ko GN, Davidson M (1991). Dopamine in schizophrenia: a review and reconceptualization. Am J Psychiatry 148: 1474-1486.

Dingledine R, Kleckner NW, McBain CJ (1990). The glycine coagonist site of the NMDA receptor. Adv Exp Med Biol 268: $17-26$.

Goff DC, Tsai G, Levitt J, Amico E, Manoach D, Schoenfeld DA et al (1999). A placebo-controlled trial of D-cycloserine added to conventional neuroleptics in patients with schizophrenia. Arch Gen Psychiatry 56: 21-27.

Gracy KN, Pickel VM (1996). Ultrastructural immunocytochemical localization of the $N$-methyl-D-aspartate receptor and tyrosine hydroxylase in the shell of the rat nucleus accumbens. Brain Res 739: 169-181.

Hanania T, Johnson KM (1999). Regulation of NMDA-stimulated $\left[{ }^{14} \mathrm{C}\right] \mathrm{GABA}$ and $\left[{ }^{3} \mathrm{H}\right]$ acetylcholine release by striatal glutamate and dopamine receptors. Brain Res 844: 106-117.

Herdon HJ, Godfrey FM, Brown AM, Coulton S, Evans JR, Cairns WJ (2001). Pharmacological assessment of the role of the glycine transporter GlyT-1 in mediating high-affinity glycine uptake by rat cerebral cortex and cerebellum synaptosomes. Neuropharmacology 41: 88-96.

Heresco-Levy U, Ermilov M, Lichtenberg P, Bar G, Javitt DC (2004). High dose glycine added to olanzapine and risperidone for the treatment of schizophrenia. Biol Psychiatry 55: $165-171$.

Heresco-Levy U, Javitt DC, Ebstein R, Vaas A, Lichtenberg P, Bar G et al (2005). D-Serine efficacy as add-on pharmacotherapy to risperidone and olanzapine for treatment-refractory schizophrenia. Biol Psychiatry, in press.

Heresco-Levy U, Javitt DC, Ermilov M, Mordel C, Silipo G, Lichtenstein M (1999). Efficacy of high-dose glycine in the treatment of enduring negative symptoms of schizophrenia. Arch Gen Psychiatry 56: 29-36.

Heresco-Levy U, Javitt DC, Ermilov M, Silipo G, Shimoni J (1998). Double-blind, placebo-controlled, crossover trial of D-cycloserine adjuvant therapy for treatment-resistant schizophrenia. Int $J$ Neuropsychopharmacol 1: 131-136.

Hernandez LF, Segovia G, Mora F (2003). Effects of activation of NMDA and AMPA glutamate receptors on the extracellular concentrations of dopamine, acetylcholine, and GABA in striatum of the awake rat: a microdialysis study. Neurochem Res 28: 1819-1827.
Hirsch SR, Das I, Garey LJ, de Belleroche J (1997). A pivotal role for glutamate in the pathogenesis of schizophrenia, and its cognitive dysfunction. Pharmacol Biochem Behav 56: 797-802.

Javitt DC (1987). Negative schizophrenic symptomatology and the phencyclidine (PCP) model of schizophrenia. Hillside J Psychiatry 9: 12-35.

Javitt DC (2001). Management of negative symptoms of schizophrenia. Curr Psychiatry Rep 3: 413-417.

Javitt DC (2002). Glycine modulators in schizophrenia. Curr Opin Investig Drugs 3: 1067-1072.

Javitt DC (2004). Glutamate as a therapeutic target in psychiatric disorders. Mol Psychiatry 9: 984-987.

Javitt DC, Balla A, Burch S, Suckow R, Xie S, Sershen H (2003). Reversal of phencyclidine-induced dopaminergic dysregulation by $N$-methyl-D-aspartate receptor/glycine-site agonists. Neuropsychopharmacology 29: 300-307.

Javitt DC, Balla A, Sershen H, Lajtha A (1999). A.E. Bennett Research Award. Reversal of phencyclidine-induced effects by glycine and glycine transport inhibitors. Biol Psychiatry 45: 668-679.

Javitt DC, Frusciante M (1997). Glycyldodecylamide, a phencyclidine behavioral antagonist, blocks cortical glycine uptake: implications for schizophrenia and substance abuse. Psychopharmacology (Berl) 129: 96-98.

Javitt DC, Sershen H, Hashim A, Lajtha A (1997). Reversal of phencyclidine-induced hyperactivity by glycine and the glycine uptake inhibitor glycyldodecylamide. Neuropsychopharmacology 17: 202-204.

Javitt DC, Sershen H, Hashim A, Lajtha A (2000). Inhibition of striatal dopamine release by glycine and glycyldodecylamide. Brain Res Bull 52: 213-216.

Javitt DC, Silipo G, Cienfuegos A, Shelley AM, Bark N, Park M et al (2001). Adjunctive high-dose glycine in the treatment of schizophrenia. Int J Neuropsychopharmacol 4: 385-392.

Javitt DC, Zukin SR (1991). Recent advances in the phencyclidine model of schizophrenia. Am J Psychiatry 148: 1301-1308.

Javitt DC, Zylberman I, Zukin SR, Heresco-Levy U, Lindenmayer JP (1994). Amelioration of negative symptoms in schizophrenia by glycine. Am J Psychiatry 151: 1234-1236.

Kegeles LS, Abi-Dargham A, Zea-Ponce Y, Rodenhiser-Hill J, Mann JJ, Van Heertum RL et al (2000). Modulation of amphetamineinduced striatal dopamine release by ketamine in humans: implications for schizophrenia. Biol Psychiatry 48: 627-640.

Kerr DI, Ong J, Prager RH, Gynther BD, Curtis DR (1987). Phaclofen: a peripheral and central baclofen antagonist. Brain Res 405: 150-154.

Kinney GG, Sur C, Burno M, Mallorga PJ, Williams JB, Figueroa DJ et al (2003). The glycine transporter type 1 inhibitor $\mathrm{N}$-[3-(4'fluorophenyl)-3-(4'-phenylphenoxy)propyl] sarcosine potentiates NMDA receptor-mediated responses in vivo and produces an antipsychotic profile in rodent behavior. J Neurosci 23: 7586-7591.

Krebs MO, Desce JM, Kemel ML, Gauchy C, Godeheu G, Cheramy A et al (1991). Glutamatergic control of dopamine release in the rat striatum: evidence for presynaptic $N$-methyl-D-aspartate receptors on dopaminergic nerve terminals. J Neurochem 56: 81-85.

Laruelle M (1998). Imaging dopamine transmission in schizophrenia. A review and meta-analysis. Q J Nucl Med 42: 211-221.

Laruelle M, Abi-Dargham A, Gil R, Kegeles LS, Innis R (1999). Increased dopamine transmission in schizoprenia: relationship to illness phases. Biol Psychiatry 46: 56-72.

Laruelle M, Abi-Dargham A, van Dyck CH, Gil R, D'Souza CD, Erdos J et al (1996). Single photon emission computerized tomography imaging of amphetamine-induced dopamine release in drug-free schizophrenic subjects. Proc Natl Acad Sci USA 93: 9235-9240. 
Le Pen G, Kew J, Alberati D, Borroni E, Heitz MP, Moreau JL (2003). Prepulse inhibition deficits of the startle reflex in neonatal ventral hippocampal-lesioned rats: reversal by glycine and a glycine transporter inhibitor. Biol Psychiatry 54: 1162-1170.

Leviel V, Gobert A, Guibert B (1989). Direct observation of dopamine compartmentation in striatal nerve terminal by 'in vivo' measurement of the specific activity of released dopamine. Brain Res 499: 205-213.

Lopez-Corcuera B, Geerlings A, Aragon C (2001). Glycine neurotransmitter transporters: an update. Mol Membr Biol 18: 13-20.

Mallorga PJ, Williams JB, Jacobson M, Marques R, Chaudhary A, Conn PJ et al (2003). Pharmacology and expression analysis of glycine transporter GlyT1 with [(3) H]-( $N$-[3-(4'-fluorophenyl)3-(4'phenylphenoxy)propyl])sarcosine. Neuropharmacology 45: 585-593.

McBain CJ, Kleckner NW, Wyrick S, Dingledine R (1989). Structural requirements for activation of the glycine coagonist site of $N$-methyl-D-aspartate receptors expressed in Xenopus oocytes. Mol Pharmacol 36: 556-565.

Miller DW, Abercrombie ED (1996). Effects of MK-801 on spontaneous and amphetamine-stimulated dopamine release in striatum measured with in vivo microdialysis in awake rats. Brain Res Bull 40: 57-62.

Miyamoto Y, Yamada K, Noda Y, Mori H, Mishina M, Nabeshima $\mathrm{T}$ (2001). Hyperfunction of dopaminergic and serotonergic neuronal systems in mice lacking the NMDA receptor epsilon 1 subunit. J Neurosci 21: 750-757.

Moghaddam B, Jackson ME (2003). Glutamatergic animal models of schizophrenia. Ann N Y Acad Sci 1003: 131-137.

Moore H, West AR, Grace AA (1999). The regulation of forebrain dopamine transmission: relevance to the pathophysiology and psychopathology of schizophrenia. Biol Psychiatry 46: 40-55.

Nankai M, Fage D, Carter C (1995). Striatal NMDA receptor subtypes: the pharmacology of $N$-methyl-D-aspartate-evoked dopamine, gamma-aminobutyric acid, acetylcholine and spermidine release. Eur J Pharmacol 286: 61-70.

Olney JW, Newcomer JW, Farber NB (1999). NMDA receptor hypofunction model of schizophrenia. J Psychiatr Res 33: 523-533.

Reynolds IJ, Miller RJ (1990). Allosteric modulation of N-methyl-Daspartate receptors. Adv Pharmacol 21: 101-126.
Schiffer WK, Logan J, Dewey SL (2003). Positron emission tomography studies of potential mechanisms underlying phencyclidine-induced alterations in striatal dopamine. Neuropsychopharmacology 28: 2192-2198.

Smith KE, Borden LA, Hartig PR, Branchek T, Weinshank RL (1992). Cloning and expression of a glycine transporter reveal colocalization with NMDA receptors. Neuron 8: 927-935.

Smolders I, De Klippel N, Sarre S, Ebinger G, Michotte Y (1995). Tonic GABA-ergic modulation of striatal dopamine release studied by in vivo microdialysis in the freely moving rat. Eur $J$ Pharmacol 284: 83-91.

Stauch Slusher B, Rissolo KC, Jackson PF, Pullan LM (1994). Centrally-administered glycine antagonists increase locomotion in monoamine-depleted mice. J Neural Transm Gen Sect 97: 175-185.

Supplisson S, Bergman C (1997). Control of NMDA receptor activation by a glycine transporter co-expressed in Xenopus oocytes. J Neurosci 17: 4580-4590.

Taber MT, Baker GB, Fibiger HC (1996). Glutamate receptor agonists decrease extracellular dopamine in the rat nucleus accumbens in vivo. Synapse 24: 165-172.

Teoh H, Malcangio M, Bowery NG (1996). GABA, glutamate and substance P-like immunoreactivity release: effects of novel GABAB antagonists. Br J Pharmacol 118: 1153-1160.

Toth E, Weiss B, Banay-Schwartz M, Lajtha A (1986). Effect of glycine derivatives on behavioral changes induced by 3-mercaptopropionic acid or phencyclidine in mice. Res Comm Psychol Psychiat Behav 11: 1-9.

Tsai G, Lane H-Y, Yang P, Chong MY, Lange N (2004). Glycine transporter-I inhibitor, $N$-methylglycine (sarcosine), added to antipsychotics for the treatment of schizophrenia. Biol Psychiatry 55: 452-456.

Tsai G, Yang P, Chung LC, Lange N, Coyle JT (1998). D-Serine added to antipsychotics for the treatment of schizophrenia. Biol Psychiatry 44: 1081-1089.

Wang JK (1991). Presynaptic glutamate receptors modulate dopamine release from striatal synaptosomes. J Neurochem 57: 819-822.

Wu Y, Pearl SM, Zigmond MJ, Michael AC (2000). Inhibitory glutamatergic regulation of evoked dopamine release in striatum. Neuroscience 96: 65-72. 